\title{
An Empirical Assessment of the Impact of Nigerian all Share Index, Market Capitalization, and Number of Equities on Gross Domestic Product
}

\author{
Obubu Maxwell, Obiora-Ilouno Happiness, Uzuke Chinwendu Alice, Ikediuwa Udoka Chinedu \\ Department of Statistics, Nnamdi Azikiwe University, Awka, Nigeria \\ Email: maxwellobubu@gmail.com
}

How to cite this paper: Maxwell, O., Happiness, O.-I., Alice, U.C. and Chinedu, I.U. (2018) An Empirical Assessment of the Impact of Nigerian all Share Index, Market Capitalization, and Number of Equities on Gross Domestic Product. Open Journal of Statistics, 8, 584-602.

https://doi.org/10.4236/ojs.2018.83038

Received: October 26, 2017

Accepted: June 22, 2018

Published: June 25, 2018

Copyright $\odot 2018$ by authors and Scientific Research Publishing Inc. This work is licensed under the Creative Commons Attribution International License (CC BY 4.0).

http://creativecommons.org/licenses/by/4.0/

(c) () Open Access

\begin{abstract}
A stock exchange is an exchange where stock brokers and traders can buy and sell shares of stock, bonds, and other securities. All listings are included in the Nigerian Stock Exchange All Shares index. In terms of market capitalization, the Nigerian Stock Exchange is the third largest stock exchange in Africa. Objectives: The paper assesses the impact of Nigerian Stock Market (all share index, market capitalization, and number of equities) on Gross domestic product (Economic Growth). Materials and Methods: Regression analysis and ordinary least square technique were employed. Result and Discussion: The series was stationary at $1 \%, 5 \%$, and $10 \% \alpha$ level; the residuals were normally distributed but not serially correlated at 5\% $\alpha$ level. All Share Index, Market Capitalization and Total Number of listed Equities have a joint and individual significant effect on Economic Growth (Gross Domestic Product) with Total Number of listed Equities having a negative (opposite) linear relationship with the Gross Domestic Product. The Durbin-Watson statistics $\left(R^{2}\right.$ $=0.9910<\mathrm{DW}=1.3686$ ) suggest that the model is not spurious and it is devoid of positive and negative autocorrelation $\left(\mathrm{DW}=1.3686>d_{l}=1.07\right.$ and $\left.\mathrm{DW}=1.5033<4-d_{u}=2.17\right)$. Therefore, it can produce meaningful result when used for forecasting a positive relationship between gross domestic product, all share index and market capitalization with a $99.1 \% \mathrm{R}$-square value. Significant Positive connection between all share index, market capitalization, the number of equities and gross domestic product suggests that government policies and bills aimed towards rapid development of the capital market should be initiated.
\end{abstract}

\section{Keywords}

Nigerian Stock Market, Gross Domestic Product, Market Capitalization, All 
Share Index, Augmented Dickey-Fuller Test, Breusch-Godfrey Test, Serial Correlation Lm Test

\section{Introduction}

Capital Market is a financial market involving institutions that deal with securities with a life of more than one year. The Nigerian Capital Market of Nigerian Stock Exchange is a major player in the market for long-term funds. The instruments or securities traded in the capital market are known as capital market instruments. However, the capital market has both securities based segment (i.e. the stock exchange) and non-securities based segment (market for long term loans) [1]. Capital market instruments can be categorized into 3 major groups of securities: preference shares, ordinary shares and debt instruments. Some of the other principal and active market operators in the Nigerian Stock Market include Stockbrokers, Investment Advisers, Issuing Houses, Registrars, Fund Managers, Financial Advisers et cetera [2]. The Nigerian Stock exchange is the center point of the Nigerian Capital Market. It provides a mechanism to mobilize private and public savings as well as making such funds available for productive purposes. The Nigerian Stock Exchange also assists in the allocation of the nation's capital resources amongst numerous competitive alternatives [3]. The stock exchange can also be a mechanism, which can measure and detect the symptoms of an impending economic boom or decline long before the predicted prosperity or decline actually occurs provided the market is either in the semi-strong or strong form of efficiency level. It is good to distinguish the capital market from the Stock Exchange in the sense that the capital market is much wider and bigger than the Stock Exchange. The Stock Exchange is just a participating institution in the capital market albeit it is the most active of all the participants [4] [5]. The activity of the Stock Exchange in the capital market is reflected by the Stock Exchange, which measures the activities on the capital market. The main objectives of the Nigerian Stock Exchange as enunciated in the Memorandum of Association of the company are to create an appropriate mechanism for capital formation and provide efficient allocation of resources among competing alternatives. It is also expected to provide special financing strategies for projects with long term gestation periods [5]. In addition, it helps to maintain discipline in the capital market as far as the participants and the investors are concerned, and as such, assists to broaden the share ownership in the market by providing the enabling environment and to provide and maintain fair prices for securities. The overriding objective of any financial system is the provision of a conducive atmosphere for the transfer of funds from the surplus sector of the economy to the deficit sector [6]. The Capital Market, in the process of carrying out its function, is faced with many challenges such as the effect of economic trends, financial restructuring and reforms by government, industrialization, and technology etc. The Capital Market is thereby required to adapt to 
the constantly changing trends in the economy. The market in Nigeria has been described as being shallow; this is due mainly to the market float that is very small and is measured by the ratio of securities in the market to the total listed securities outstanding. The challenge that lies ahead is to be able to increase and retain as many of our domestic individual and institutional investors as possible and simultaneously attract foreign ones to the Nigerian Capital Market. This can be achieved by being dynamic, innovative, and having an open mind so that new ideas can be absorbed and put productively in use. The market must be in a position to provide a spectrum of investment alternatives, new trading instruments with which investors can hedge their risk, as well as an environment which is honest that has sufficient structures and where policies are flexible enough to accommodate different investment needs [7] [8] [9] [10]. The Capital market has also been characterized by a number of market failures, one of which is asymmetric information, a situation in which one party to a transaction has less information than the other party. The pervasiveness of this phenomenon greatly undermines the efficiency of financial markets as mechanisms for allocating resources [11] [12] [13]. Because geography and cultural distance complicate the acquisition information, asymmetric information is particularly prevalent globally. While the revolution in information asymmetric is lessened but not eliminated, therefore they are prone to the sharp investor reactions, unpredictable market movements and financial crisis that can occur when information is incomplete and financial markets behave erratically [14] [15] [16] [17]. Thus, in the absence of complete information, investors tend to rush in and out of the markets on rumor. The specific objectives of this paper are to present a working model for the Nigerian Capital Market as it relates to the Nigerian Economic Growth, to examine if Market Capitalization contributes to Economic growth and if the all share index contributes to Nigeria Economic growth.

\section{Materials and Method}

The data for this study was extracted from Central Bank of Nigeria Annual reports and Statistical Bulletin (Various Issues) from the National Bureau of Statistics. The time series data cover a period of 1961 to 2017. In an attempt to investigate the impact of the Nigerian stock market on (all share index, market capitalization, and number of equities) Nigerian economy the following models were employed;

\subsection{Multiple Linear Regression Model and Population Regression Function}

The model is specified based on Demirguc-Kunt and Levine (1996) theory on the relationship between stock market earning and economic growth [18].

$$
Y_{1}=f\left(X_{1}, X_{2}, \ldots, X_{k}, e\right)
$$

where; $Y_{l}$ is Dependent variable, $X_{l}, X_{2}, \ldots, X_{k}$ are the Independent variables, $e$ is the error term. Thus, the specific multiple linear regression model is formulated 
as:

$$
\mathrm{GDP}_{t}=f\left(\mathrm{MC}_{t}, \mathrm{TR}_{t}, \mathrm{ASI}_{t}, \mathrm{MCR}_{t}, \mathrm{NOD}_{t}, \mathrm{VOT}_{t}, \mathrm{VR}_{t}, \mathrm{TNL}_{t}\right)
$$

The model be explicitly stated as:

$$
\begin{aligned}
\mathrm{GDP}_{t} & =\beta_{0}+\beta_{1} \mathrm{MC}_{t}+\beta_{2} \mathrm{ASI}_{t}+\beta_{3} \mathrm{TR}_{t}+\beta_{4} \mathrm{MCR}_{t} \\
& +\beta_{5} \mathrm{NOD}_{t}+\beta_{6} \mathrm{VOT}_{t}+\beta_{7} \mathrm{VR}_{t}+\beta_{8} \mathrm{TNL}_{t}+e t_{t}
\end{aligned}
$$

On taking natural logarithm of the variables to fit the model, the resulting estimation equation is given as:

$$
\begin{aligned}
\log \mathrm{GDP}_{t} & =\beta_{1} \log \mathrm{MC}_{t}+\beta_{2} \log \mathrm{ASI}_{t}+\beta_{3} \log \mathrm{TR}_{t}+\beta_{4} \log \mathrm{MCR}_{t} \\
& +\beta_{5} \log \mathrm{NOD}_{t}+\beta_{6} \log \left(\mathrm{VOT}_{t}-1\right)+\beta_{7} \log \mathrm{VR}_{t}- \\
& +\beta_{8} \log \mathrm{TNL}_{t}+e t_{t}
\end{aligned}
$$

where the priori expectation is $\beta_{1}>\beta_{2}>\beta_{3}>\beta_{4}>\beta_{5} \beta_{6}>\beta_{7}>\beta_{8}>0$.

GDP, ASI, MC, MCR, TR, VR, NOD represents Gross Domestic Product, All Share Index, Market Capitalization, Market Capitalization Ratio, Turnover Ratio, Total Value of Shares Traded Ratio, Total Number of Deal, Value of Transaction, Total number of listed equities respectively.

\subsection{Augmented Dickey-Fuller Test}

An augmented dickey-fuller test is a test for a unit root in a time series sample [18]. The augmented dickey-fuller statistic, used in this test, is a negative number. The more negative it is, the stronger the rejection of the hypothesis that there is a unit root at some level of confidence.

Testing Procedure

$\mathrm{H}_{0}: \gamma=0 ; \mathrm{H}_{1}: \gamma<0$

$$
\mathrm{DF}_{T}=\frac{\hat{\gamma}}{\mathrm{SE}(\hat{\gamma})}
$$

Once a value for the test statistic above, is computed it can be compared to the relevant critical value for the Dickey-Fuller Test. If the test statistic is less (this test is non-symmetrical so we do not consider an absolute value) than the (larger negative) critical value, then the null hypothesis of $\gamma=0$ is rejected and no unit root is present [18].

\subsection{Breusch-Godfrey Test Serial Correlation}

The Breusch-Godfrey test is based on the idea of Lagrange multiplier testing, it is sometimes referred to as LM test for serial correlation [18] [19]. It is used to assess the validity of some of the modeling assumptions inherent in applying regression-like models to observed data series. In particular, it tests for the presence of serial dependence that has not been included in the proposed model structure and which, if present, would mean that incorrect conclusions would be drawn [20].

Consider a linear regression of any form, for example

$$
Y_{t}=\alpha_{0}+\alpha_{1} X_{t}, 1+\alpha_{2} X_{t}, 2+u_{t}
$$


where the residuals might follow an $\operatorname{AR}(p)$ autoregressive scheme, as follows:

$$
u_{t}=p_{1} u_{t-1}+p_{2} u_{t-2}+\ldots+p_{p} u_{t-p}+\varepsilon_{t}
$$

Breusch and Godfrey proved that, if the following auxiliary regression model is fitted

$$
\hat{u}_{t}=\alpha_{0}+\alpha_{1} X_{t 1}+\alpha_{2} X_{t 2}+p_{1} u_{t-1}+p_{2} u_{t-2}+\varepsilon_{t}
$$

And if the usual $R^{2}$ statistic is calculated for this model, then the following asymptotic approximation can be used for the distribution of the test statistic [20].

$$
n R^{2} \sim X_{p}^{2}
$$

when the null hypothesis $\mathrm{H}_{0}:\{p i=0$ foralli $\}$ holds (that is, there is no serial correlation of any order up to $p$ ). Here $\mathrm{n}$ is the number of data-points available for the second regression, that for $\hat{u}_{t}$

$$
n=T-p
$$

where $T$ is the number of observations in the basic series. Note that the value of $\mathrm{n}$ depends on the number of lags of the error term $(p)$.

\subsection{Jarque-Bera Test for Normality}

Where $n$ is the number of observations and $k$ is the number of regressors when examining residuals to an equation.

$$
\begin{gathered}
\mathrm{JB}=\frac{n-k}{6}\left(S^{2}+\frac{1}{4}(C-3)^{2}\right) \\
\left.\mathrm{LM}=\left[\begin{array}{c}
\partial l \\
\partial \theta
\end{array}\right]^{!}\left[\begin{array}{c}
\partial^{2} l \\
-E \\
\delta \theta(\delta \theta)^{!}
\end{array}\right]\right]^{-1}\left[\begin{array}{c}
\partial l \\
\partial \theta
\end{array}\right] \sim X_{p-1}^{2}
\end{gathered}
$$

Under the null hypothesis of Homoscedasticity.

\section{Results and Discussion}

\subsection{Stationarity Test}

\section{1) Statement of Hypothesis}

$\mathrm{H}_{\mathrm{o}}$ : There is unit root in the series.

$\mathrm{H}_{1}$ : There is no unit root in the series (the series are stationary)

\section{2) Decision Rule}

Reject Null Hypothesis if the p-value is less than the level of significance (Figures 1-9).

From Table 1, we can deduce that all the series are stationary at $1 \%, 5 \%$ and $10 \%$ level of significance at first difference.

The descriptive statistics Table 2 shows the mean, median, standard deviation, Skewness, kurtosis, and number of observations of all the variables entered.

The correlation matrix shows the nature and strength of the linear association or relationship between all the variables entered [22] (Table 3). 


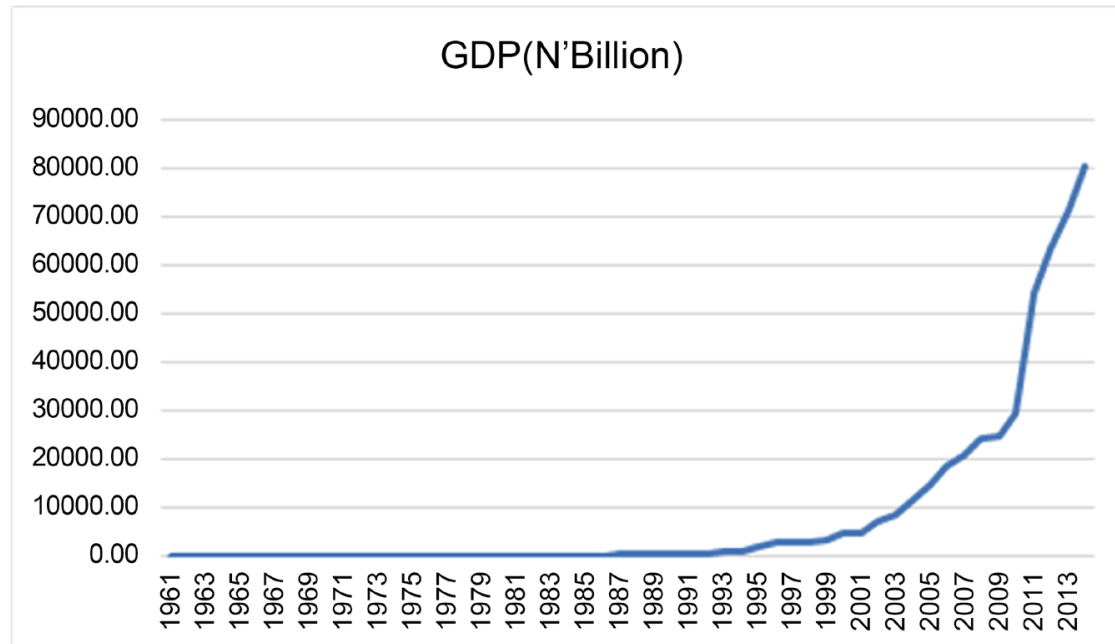

Figure 1. Time plot of gross domestic product for a period of 1961 to 2015 [21].

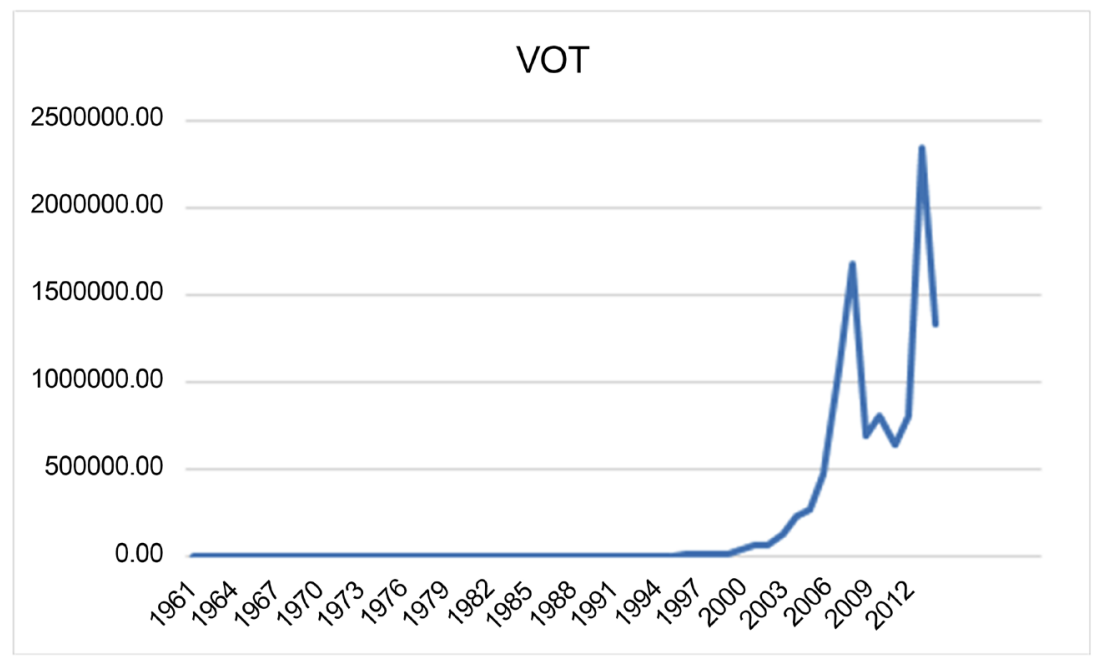

Figure 2. Time plot of value of transaction for a period of 1961 to 2015 [21].



Figure 3. Time plot of total number of equities listed for a period of 1961 to 2015 [21]. 


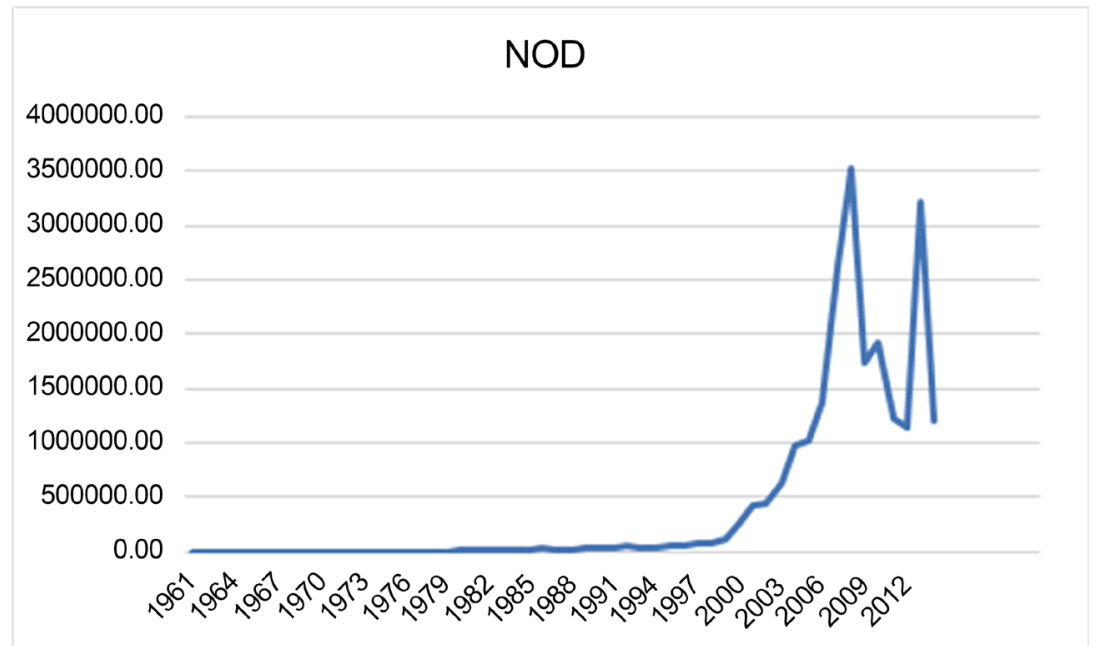

Figure 4. Time plot of number of deals for a period of 1961 to 2015 [21].

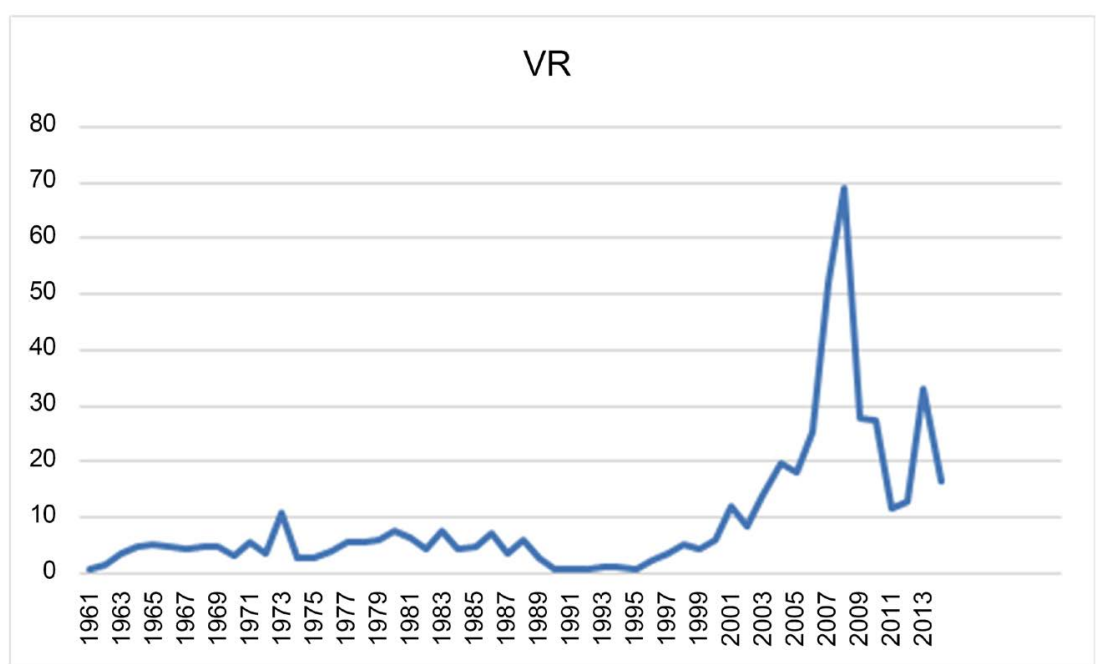

Figure 5. Time plot of total value of shares traded ratio from 1961 to 2015 [21].

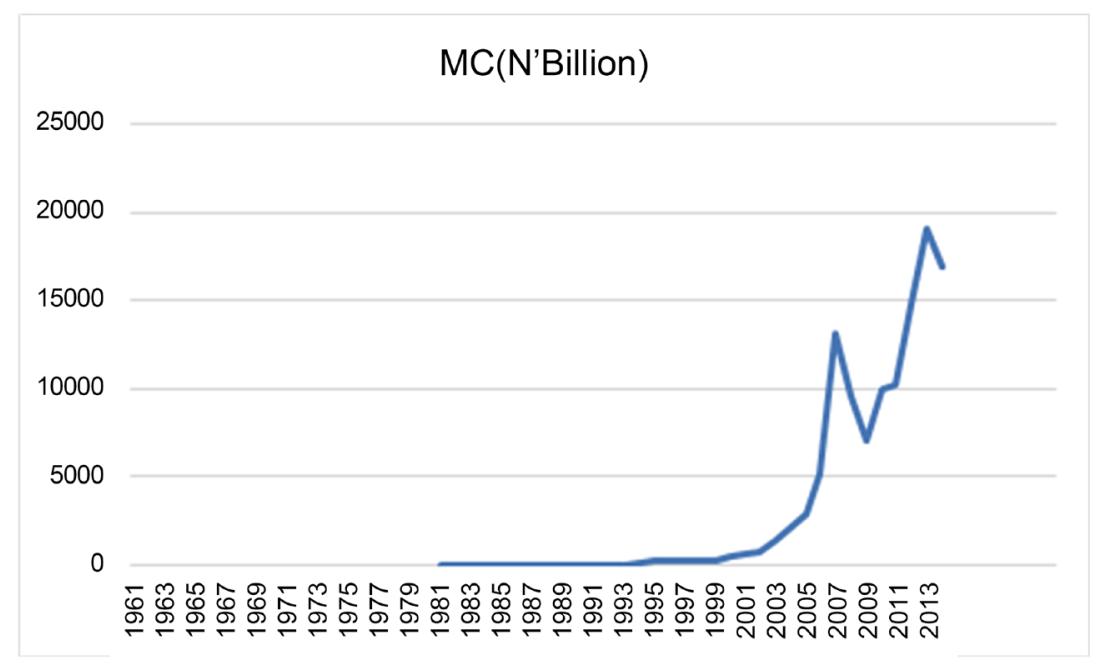

Figure 6. Time plot of market capitalization for a period of 1961 to 2015 [21]. 


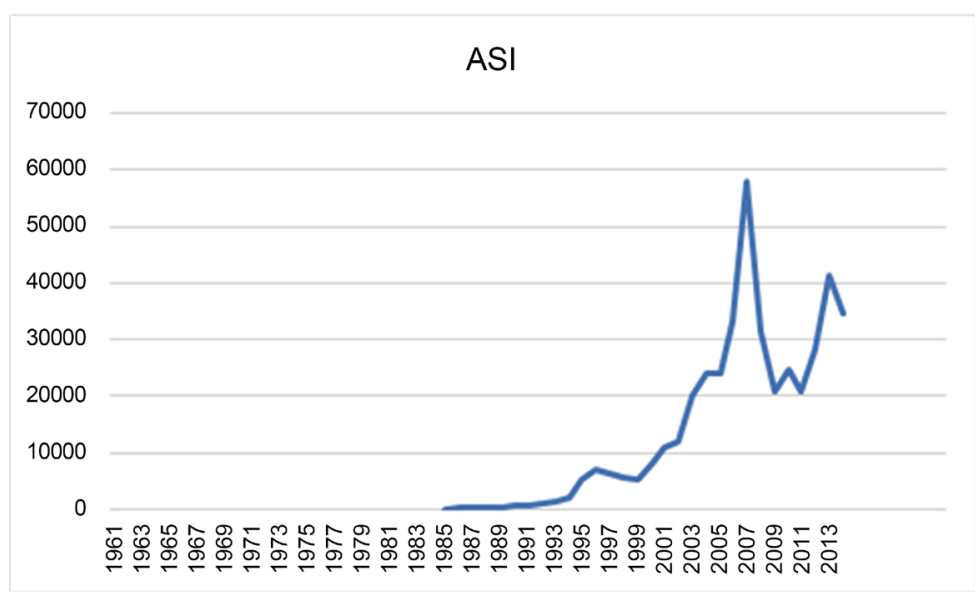

Figure 7. Time plot of all share index for a period of 1961 to 2015 [21].

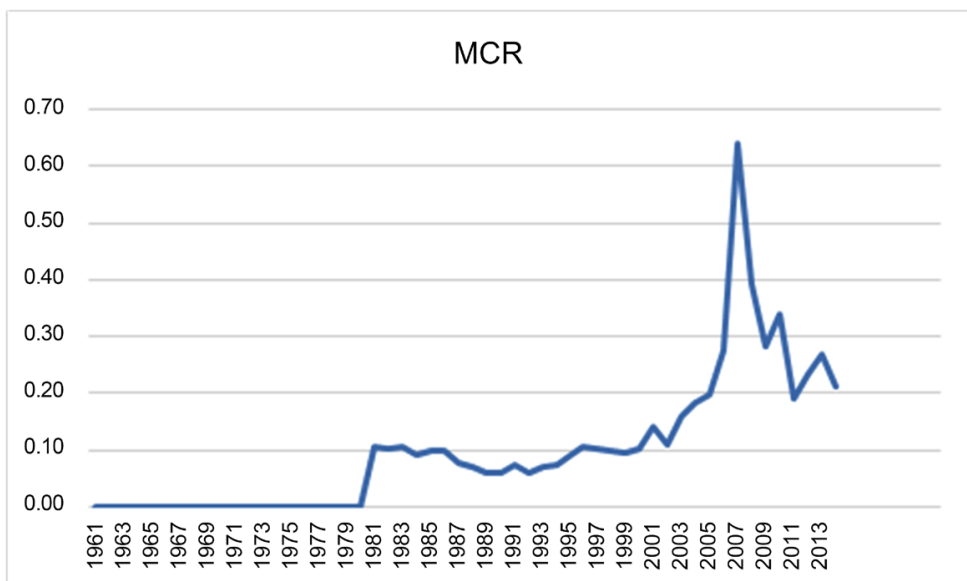

Figure 8. Time plot of market capitalization ratio for a period of 1961 to 2015 [21].

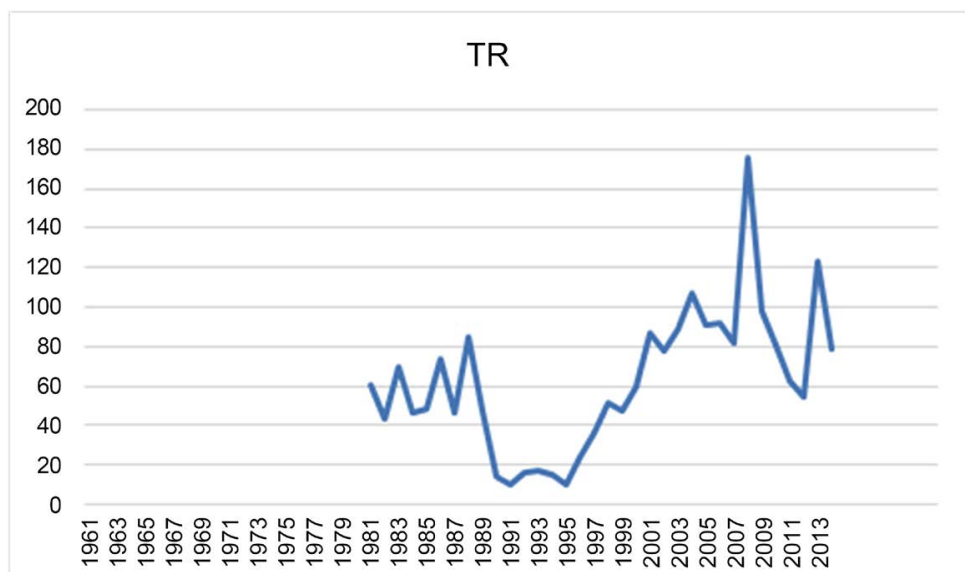

Figure 9. Time plot of turnover ratio for period of 1961 to 2015 [21].

From Table 4, we can deduce that All Share Index, Market Capitalization, and Total Number of listed Equities have a joint and individual significant effect on Economic Growth (Gross Domestic Product) with Total Number of listed 
Table 1. Unit root test.

\begin{tabular}{|c|c|c|c|c|}
\hline \multicolumn{5}{|l|}{ Group unit root test: Summary } \\
\hline \multicolumn{5}{|c|}{ Series: ASI, GDP, MC, NOD, MCR, TNL, TR, VOT, VR } \\
\hline \multicolumn{5}{|l|}{ Sample: 19612015} \\
\hline \multicolumn{5}{|c|}{ Exogenous variables: Individual effects } \\
\hline \multicolumn{5}{|c|}{ Automatic selection of maximum lags } \\
\hline \multicolumn{5}{|c|}{ Automatic lag length selection based on SIC: 0 to 10} \\
\hline \multicolumn{5}{|c|}{ Newey-West automatic bandwidth selection and Bartlett kernel } \\
\hline Method & Statistic & Prob. ${ }^{* *}$ & Cross-Section & Obs \\
\hline \multicolumn{5}{|c|}{ Null: Unit root (assumes common unit root process) } \\
\hline Levin, Lin \& Chu $t^{\star}$ & 5.67259 & 1.0000 & 9 & 376 \\
\hline \multicolumn{5}{|c|}{ Null: Unit root (assumes individual unit root process) } \\
\hline Im, Pesaran and Shin W-stat & -9.12436 & 0.0000 & 9 & 376 \\
\hline ADF-Fisher Chi-square & 214.151 & 0.0000 & 9 & 376 \\
\hline PP-Fisher Chi-square & 294.143 & 0.0000 & 9 & 404 \\
\hline
\end{tabular}

${ }^{*}$ Probabilities for Fisher tests are computed using an asymptotic Chi-square distribution. All other tests assume asymptotic normality.

Table 2. Descriptive statistics.

\begin{tabular}{|c|c|c|c|c|c|c|c|c|c|}
\hline & ASI & GDP & $\mathrm{MC}$ & NOD & MCR & TNL & TR & VOT & VR \\
\hline Mean & 14298.43 & 15123.82 & 3855.149 & 749285.0 & 0.165418 & 257.83336 & 63.30438 & 355040.8 & 13.35541 \\
\hline Median & 7551.550 & 3888.050 & 386.1500 & 190016.0 & 11 & 06 & 60.8 & 21 & 6.674824 \\
\hline Maximum & 57990.20 & 80222.13 & 19077.42 & 3535631. & 0.638113 & 310.00001 & 175.5881 & 2350876 & 69.11109 \\
\hline Minin & 127.3000 & 67.90000 & 6.600000 & 20525.00 & 0.058581 & 192.00001 & 10.19290 & 225.4000 & 0.775713 \\
\hline Std. Dev. & 15049 & 2270 & 270 & 9945 & 0.12 & 3 & 38.05 & 58 & 15.91670 \\
\hline Skewness & 1.040999 & 1.745152 & 1.358914 & 1.464166 & 2.013925 & -0.722850 & 0.649929 & 1.906407 & 1.984217 \\
\hline Kurtosis & 3.481675 & 4.859729 & 3.474663 & 4.259655 & 7.564 & 2.9 & 3.732 & 6.0 & 6.879386 \\
\hline Jarq & 5.7 & 19 & 1 & 12 & 40 & 2.6138 & 2.783575 & 30 & 38.49762 \\
\hline Probability & 0.057602 & 0.000057 & 0.008588 & 0.001745 & 0.0 & 0.2 & 0.24 & 00 & 0.000000 \\
\hline Sum & 428952.8 & 45 & 11 & 22 & 4. & 77 & 189 & 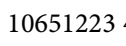 & 340 \\
\hline mSq.D & $6.57 \mathrm{E}+\mathrm{C}$ & 1.50 & $9.83 \mathrm{E}+\mathrm{C}$ & $2.87 \mathrm{E}$ & 0.4668 & 26382. & 41987. & $1.00 \mathrm{E}+13$ & 37346.902 \\
\hline Obs & J & 50 & 30 & 30 & 30 & 30 & 30 & 30 & 3 \\
\hline
\end{tabular}

Table 3. Correlation matrix [22].

\begin{tabular}{cccccccccc}
\hline & ASI & GDP & MC & NOD & MCR & TNL & TR & VOT & VR \\
\hline ASI & 1.000000 & 0.706603 & 0.846723 & 0.873031 & 0.908835 & 0.004468 & 0.655509 & 0.809969 & 0.819825 \\
GDP & 0.706603 & 1.000000 & 0.942002 & 0.656189 & 0.485947 & -0.604801 & 0.427905 & 0.824907 & 0.438062 \\
MC & 0.846723 & 0.942002 & 1.000000 & 0.823674 & 0.721172 & -0.413788 & 0.518279 & 0.923671 & 0.653361 \\
NOD & 0.873031 & 0.656189 & 0.823674 & 1.000000 & 0.866097 & 0.014404 & 0.782894 & 0.924371 & 0.939214 \\
MCR & 0.908835 & 0.485947 & 0.721172 & 0.866097 & 1.000000 & 0.203256 & 0.617928 & 0.710672 & 0.899938 \\
TNL & 0.004468 & $-0.604801-0.413788$ & 0.014404 & 0.203256 & 1.000000 & 0.043691 & -0.263364 & 0.242926 \\
TR & 0.655509 & 0.427905 & 0.518279 & 0.782894 & 0.617928 & 0.043691 & 1.000000 & 0.668873 & 0.825388 \\
VOT & 0.809969 & 0.824907 & 0.923671 & 0.924371 & 0.710672 & -0.263364 & 0.668873 & 1.000000 & 0.783735 \\
VR & 0.819825 & 0.438062 & 0.653361 & 0.939214 & 0.899938 & 0.242926 & 0.825388 & 0.783735 & 1.000000 \\
\hline
\end{tabular}


Table 4. Model summary [23].

\begin{tabular}{|c|c|c|c|c|}
\hline \multicolumn{5}{|c|}{ Dependent Variable: LOG (GDP) } \\
\hline \multicolumn{5}{|c|}{ Sample (adjusted): 19852015} \\
\hline \multicolumn{5}{|c|}{ Included observations: 30 after adjustments } \\
\hline Variable & Coefficient & Std. Error & t-Statistic & Prob. \\
\hline $\mathrm{C}$ & 11.14131 & 2.068004 & 5.387471 & 0.0000 \\
\hline LOG (ASI) & 0.516532 & 0.103574 & 4.987065 & 0.0000 \\
\hline LOG (MC) & 0.438354 & 0.072694 & 6.030117 & 0.0000 \\
\hline LOG (TNL) & -1.826293 & 0.413947 & -4.411904 & 0.0002 \\
\hline R-squared & 0.991091 & \multicolumn{2}{|c|}{ Mean dependent var } & 8.071192 \\
\hline Adjusted R-squared & 0.990063 & \multicolumn{2}{|c|}{ S.D. dependent var } & 2.195769 \\
\hline S.E. of regression & 0.218882 & \multicolumn{2}{|c|}{ Akaike info criterion } & -0.077006 \\
\hline Sum squared resid & 1.245637 & \multicolumn{2}{|c|}{ Schwarz criterion } & 0.109820 \\
\hline Log likelihood & 5.155096 & \multicolumn{2}{|c|}{ Hannan-Quinn criter. } & -0.017239 \\
\hline F-statistic & 964.1522 & \multicolumn{2}{|c|}{ Durbin-Watson stat } & 1.368608 \\
\hline Prob (F-statistic) & 0.000000 & & & \\
\hline
\end{tabular}

Equities having a negative (opposite) linear relationship with the Gross Domestic Product. R-square supposes that All Share Index, Market Capitalization, and Total Number Of Listed Equity explains the variation in Gross Domestic Product by $99.10 \%$ while adjusted R-square gives the percentage of variation (99\%) explained by only those independent variable that in reality affects the dependent variable. The Durbin-Watson statistics $\left(R^{2}=0.9910<\mathrm{DW}=1.3686\right)$ suggest that the model is not spurious and it is devoid of positive and negative autocorrelation ( $\mathrm{DW}=1.3686>d_{1}=1.07$ and $\left.\mathrm{DW}=1.5033<4-d_{u}=2.17\right)$ therefore can produce meaningful result when used for forecasting.

From Table 5, it can be seen that the Fisher Ratio (F) Statistic affirms the value of the F-Statistic in the model summary table, which verifies that All Share Index, Market Capitalization, and Total Number of listed Equities have a joint significant effect on Economic Growth (Gross Domestic Product).

\subsection{Normality Test}

\section{1) Statement of Hypothesis:}

$\mathrm{H}_{\mathrm{o}}$ : Residuals are Normally Distributed

$\mathrm{H}_{1}$ : Residuals are not Normally Distributed.

\section{2) Decision Rule:}

Reject Null Hypothesis if the p-value is less than the level of significance (5\%).

From Figure 10 we conclude that the residuals follow a normal distribution (i.e. the dependent and independent variables in the model are normally distributed) at $5 \%$ level of significance.

The standardized residual graph in Figure 11 shows the standardized residuals of the observations are less than the absolute value of 3 , it is considered 
Table 5. Analysis of variance table.

\begin{tabular}{ccccccc}
\hline & Model & Sum of Squares & Df & Mean Square & F & Sig. \\
\hline & Regression & 26.137 & 3 & 8.712 & 964.152 & $0.000^{\mathrm{b}}$ \\
1 & Residual & 0.235 & 26 & 0.009 & & \\
& Total & 26.372 & 29 & & &
\end{tabular}

a. Dependent Variable: GDP; b. Predictors: (Constant), ASI, TNL, MC.

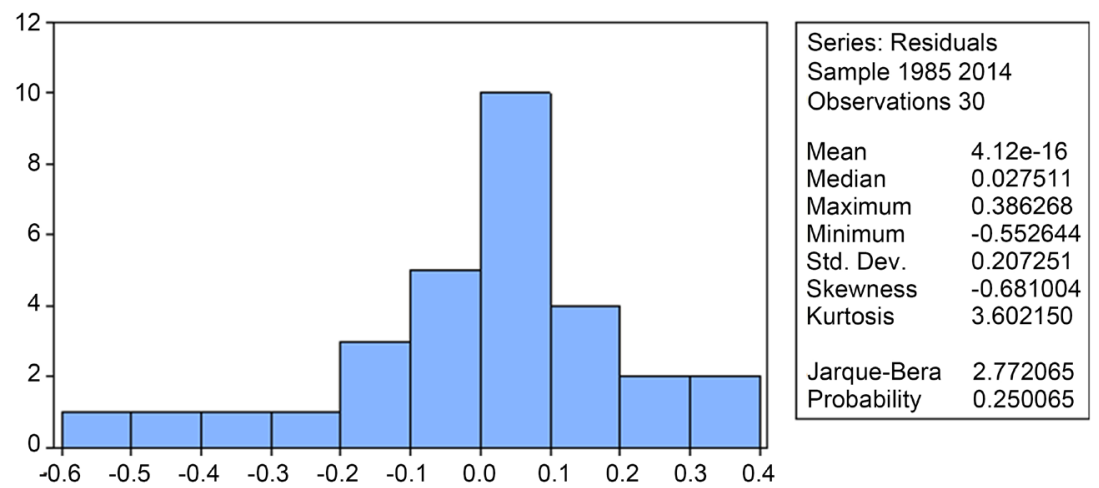

Figure10. Jarque Bera test for normality.

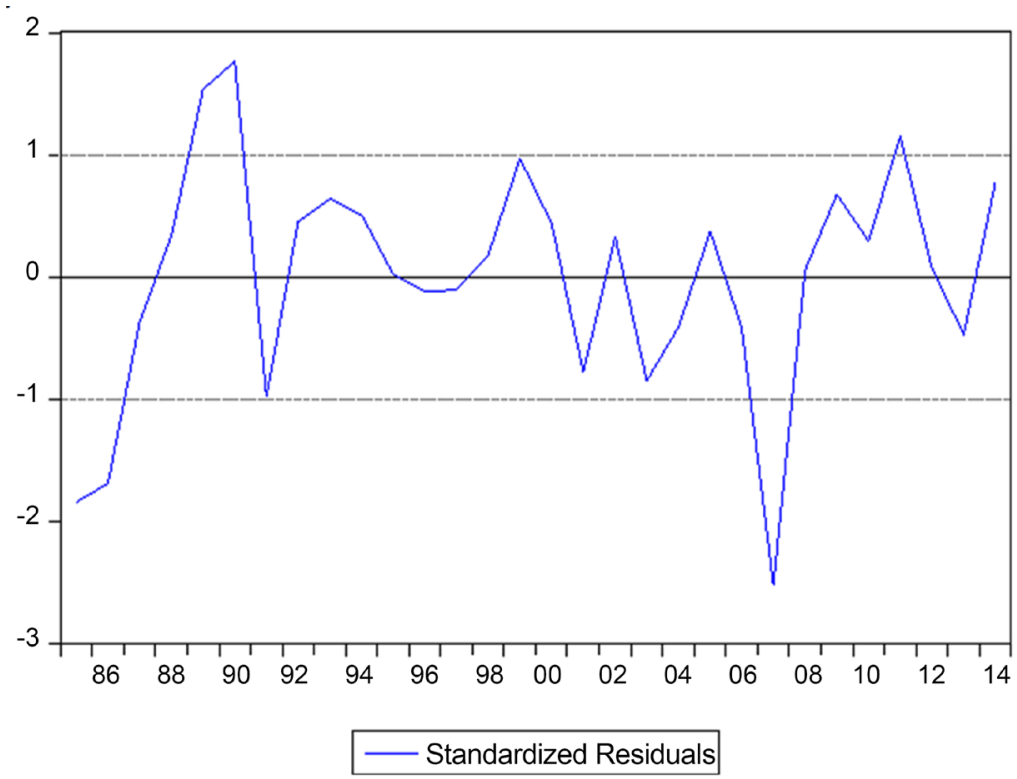

Figure 11. Standardized residual graph.

that there is no potential outlier in the observations that will distort the relationships and significant tests.

\subsection{Autocorrelation Test}

1) Statement of Hypothesis:

$\mathrm{H}_{\mathrm{o}}$ : Residuals are not serially correlated

$\mathrm{H}_{1}$ : Residuals are serially correlated 


\section{2) Decision Rule:}

Reject Null Hypothesis if the p-value is less than the level of significance (5\%).

From Table 6, we can deduce that the residuals are not serially correlated at $5 \%$ level of significance.

\subsection{Homoscedasticity Test}

\section{1) Statement of Hypothesis:}

Null Hypothesis: Residuals are not Heteroscedastic.

Alternative Hypothesis: Residuals are Heteroscedastic.

\section{2) Decision Rule:}

Reject Null Hypothesis if the p-value is less than the level of significance (5\%).

From Tables 7-9, we conclude that the residuals are homoscedastic (i.e. the variance of error or probability distribution of error is the same across all the levels of the independent variables) at 5\% level of significance.

Figure 12 \& Figure 13 shows the actual values of dependent variable, the fitted or predicted values of the dependent variable and the difference between actual values and the fitted values (i.e. the residuals).

\section{Conclusion and Recommendation}

This study attempted to assess the impact of Nigerian All Share Index, Market

Table 6. Breusch-Godfrey test serial correlation $1 \mathrm{~m}$ test [24].

\begin{tabular}{|c|c|c|c|c|}
\hline \multicolumn{5}{|c|}{ Breusch-Godfrey Serial Correlation LM Test: } \\
\hline F-statistic & 1.396825 & \multicolumn{2}{|c|}{ Prob. F(2.24) } & 0.2668 \\
\hline Obs ${ }^{\star} \mathrm{R}$-squared & 3.127961 & \multicolumn{2}{|c|}{ Prob. Chi-Square(2) } & 0.2093 \\
\hline \multicolumn{5}{|c|}{ Sample: 19852015} \\
\hline \multicolumn{5}{|c|}{ Included observations: 30} \\
\hline \multicolumn{5}{|c|}{ Presample missing value lagged residuals set to zero. } \\
\hline Variable & Coefficient & Std. Error & t-Statistic & Prob. \\
\hline $\mathrm{C}$ & 0.282962 & 2.278287 & 0.124199 & 0.9022 \\
\hline LOG (ASI) & 0.014903 & 0.119559 & 0.124650 & 0.9018 \\
\hline LOG (MC) & -0.009399 & 0.083254 & -0.112900 & 0.9110 \\
\hline LOG (TNL) & -0.063450 & 0.469886 & -0.135033 & 0.8937 \\
\hline $\operatorname{RESID}(-1)$ & 0.296479 & 0.207199 & 1.430889 & 0.1654 \\
\hline $\operatorname{RESID}(-2)$ & -0.239630 & 0.232319 & -1.031469 & 0.3126 \\
\hline R-squared & 0.104265 & \multicolumn{2}{|c|}{ Mean dependent var } & $4.12 \mathrm{E}-16$ \\
\hline Adjusted R-squared & -0.082346 & \multicolumn{2}{|c|}{ S.D. dependent var } & 0.207251 \\
\hline S.E. of regression & 0.215615 & \multicolumn{2}{|c|}{ Akaike info criterion } & -0.053784 \\
\hline Sum squared resid & 1.115760 & \multicolumn{2}{|c|}{ Schwarz criterion } & 0.226455 \\
\hline Log likelihood & 6.806762 & \multicolumn{2}{|c|}{ Hannan-Quinn criter. } & 0.035867 \\
\hline F-statistic & 0.558730 & \multicolumn{2}{|c|}{ Durbin-Watson stat } & 1.809616 \\
\hline Prob (F-statistic) & 0.730397 & & & \\
\hline
\end{tabular}


Table 7. Breusch-Pagan-Godfrey test [25].

\begin{tabular}{|c|c|c|c|c|}
\hline \multicolumn{5}{|c|}{ Heteroskedasticity Test: Breusch-Pagan-Godfrey } \\
\hline F-statistic & 2.054522 & \multicolumn{2}{|c|}{ Prob. F (3.26) } & 0.1308 \\
\hline $\mathrm{Obs}^{\star} \mathrm{R}$-squared & 5.748958 & \multicolumn{2}{|c|}{ Prob. Chi-Square (3) } & 0.1245 \\
\hline Scaled explained SS & 5.618181 & \multicolumn{2}{|c|}{ Prob. Chi-Square (3) } & 0.1317 \\
\hline \multicolumn{5}{|c|}{ Sample: 19852015} \\
\hline \multicolumn{5}{|c|}{ Included observations: 30} \\
\hline Variable & Coefficient & Std. Error & t-Statistic & Prob. \\
\hline $\mathrm{C}$ & -0.885524 & 0.611163 & -1.448916 & 0.1593 \\
\hline LOG (ASI) & -0.068391 & 0.030610 & -2.234313 & 0.0343 \\
\hline LOG (MC) & 0.043400 & 0.021484 & 2.020162 & 0.0538 \\
\hline LOG (TNL) & 0.224843 & 0.122335 & 1.837927 & 0.0775 \\
\hline R-squared & 0.191632 & \multicolumn{2}{|c|}{ Mean dependent var } & 0.041521 \\
\hline Adjusted R-squared & 0.098359 & \multicolumn{2}{|c|}{ S.D. dependent var } & 0.068124 \\
\hline S.E. of regression & 0.064687 & \multicolumn{2}{|c|}{ Akaike info criterion } & -2.514956 \\
\hline Sum squared resid & 0.108794 & \multicolumn{2}{|c|}{ Schwarz criterion } & -2.328130 \\
\hline Log likelihood & 41.72434 & \multicolumn{2}{|c|}{ Hannan-Quinn criter. } & -2.455189 \\
\hline F-statistic & 2.054522 & \multicolumn{2}{|c|}{ Durbin-Watson stat } & 2.205782 \\
\hline Prob (F-statistic) & 0.130840 & & & \\
\hline
\end{tabular}

Table 8. Actual line, fitted line and residual plot [25].

\begin{tabular}{|c|c|c|c|c|c|}
\hline obs & Actual & Fitted & Residual & & esidual Plot \\
\hline 1985 & 4.21804 & 4.62157 & -0.40353 & I & .1. \\
\hline 1986 & 4.23555 & 4.60596 & -0.37041 & | & *. | . 1 \\
\hline 1987 & 4.65586 & 4.73692 & -0.08106 & | &.${ }^{*}|\cdot|$ \\
\hline 1988 & 4.93519 & 4.86203 & 0.07316 & | & $\cdot 1^{*}$. \\
\hline 1989 & 5.37898 & 5.04292 & 0.33605 & | & . $\left|.^{*}\right|$ \\
\hline 1990 & 5.58912 & 5.20285 & 0.38627 & | & $\cdot\left|*^{*}\right|$ \\
\hline 1991 & 5.74332 & 5.95776 & -0.21444 & | & * 1. \\
\hline 1992 & 6.27777 & 6.17920 & 0.09857 & | & $\cdot 1^{*} \cdot \mid$ \\
\hline 1993 & 6.52781 & 6.38822 & 0.13959 & I & $\cdot 1^{*}$. \\
\hline 1994 & 6.80228 & 6.69186 & 0.11042 & I & $\cdot 1^{*}$ \\
\hline 1995 & 7.56693 & 7.56298 & 0.00395 & | & . ${ }^{*}$. \\
\hline 1996 & 7.90201 & 7.92845 & -0.02644 & | & $\cdot{ }^{*}|\cdot|$ \\
\hline 1997 & 7.93809 & 7.96116 & -0.02307 & | & $\cdot{ }^{*} \mid 1$ \\
\hline 1998 & 7.90411 & 7.86450 & 0.03961 & | & $\cdot 1^{*} \cdot$ \\
\hline 1999 & 8.06903 & 7.85702 & 0.21201 & | & . $1 *$ \\
\hline 2000 & 8.42991 & 8.33438 & 0.09553 & I & $\cdot 1^{*}$. \\
\hline 2001 & 8.46064 & 8.63135 & -0.17071 & I & $.^{*} \mid \cdot$ \\
\hline 2002 & 8.84107 & 8.76804 & 0.07303 & I & $\cdot 1^{*}$ \\
\hline 2003 & 9.04629 & 9.23248 & -0.18619 & | & $.^{*} \mid \cdot 1$ \\
\hline 2004 & 9.34234 & 9.43237 & -0.09002 & I & ${ }^{*} \mid$. \\
\hline 2005 & 9.58687 & 9.50534 & 0.08153 & I & $\cdot 1^{*}$. \\
\hline 2006 & 9.82901 & 9.92019 & -0.09118 & 1 & $.^{*} \mid$ \\
\hline 2007 & 9.93582 & 10.4885 & -0.55264 & $1^{*}$ & $\cdot 1$ \\
\hline
\end{tabular}




\section{Continued}

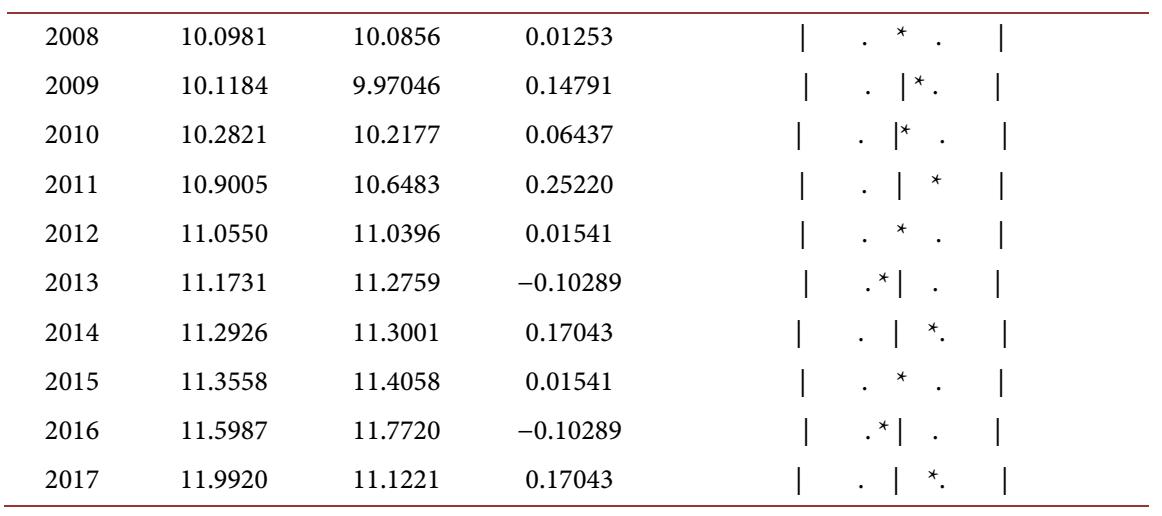

Table 9. Regression model.

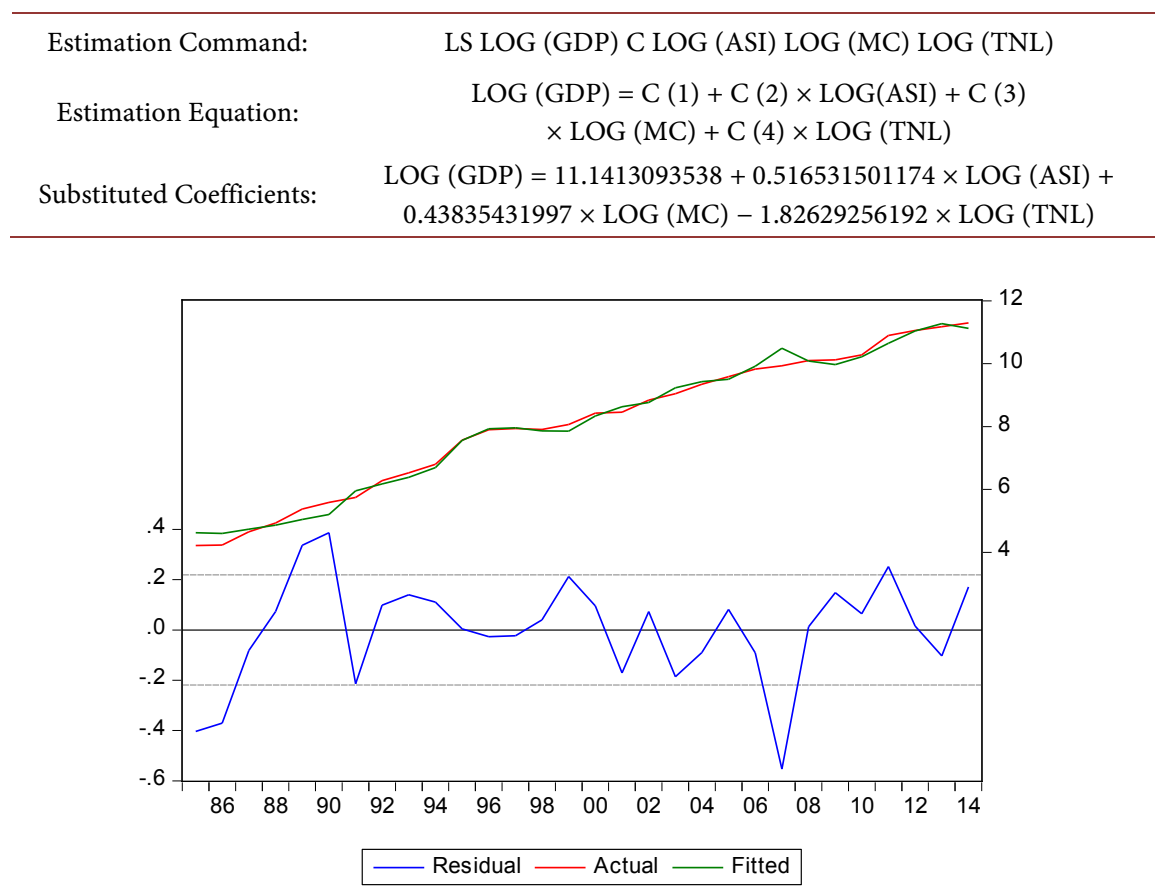

Figure 12. Actual line, fitted line and residual plot.



Figure 13. Linear graph of GDP Vs ASI, MC \& TNL. 
Capitalization, and Total Number of listed Equities on the Stock market on Gross domestic product (economic growth) between the period of 1961 and 2017, and notable stock market variables were employed, and the connection between stock market and economic growth was found to be positive. The Nigerian stock exchange is undoubtedly one of the most important contributors to the Nigerian economy. That the stock market promotes economic growth is not in doubt. The Capital market serves as an important mechanism for effective and efficient mobilization and allocation of saving, a crucial function for an economy desirous of growth. We conclude that the Nigerian Capital Market contributes positively to Economic Growth. The result suggests that for a significant growth in the economy as to be contributed by the capital market, the focus of policy should be on measure to promote growth in the stock market. Thus, we recommend that:

1) The collective effort of all stakeholders with the Federal Government leads and creates the positive environment. Also, the oversight function of this Honourable House of Representative will surely provide the required investor's confidence which will positively impact on the market. We should all work hard to ensure that our market is brought back to life by pursuing genuine measures geared towards achieving a robust stock market.

2) The regulatory authority should initiate policies and laws that would encourage more companies and the public to access the market to ensure effective and efficient functioning of the capital market.

3) Securities and Exchange Commission should be more proactive in their surveillance role in order to check sharp practices which undermine market integrity and discourage investors from the capital market.

4) Investment education should be encouraged in all facet of the population and should also be included in curriculum of higher institutions so that investors won't go in and out of the capital market blindly.

5) The funds raised by government in the form of government securities in the capital market should be put into productive sectors of the economy that will necessitate to growth in all facets of the economy.

6) Abolition of VAT on capital market transactions: VAT should NOT be imposed on capital market investments in any form; it is a disincentive to investment. Taxes should be on consumption. Hence, any form of tax including stamp duties should be removed on listed securities. The governments of Ghana, Zambia etc. have done away with VAT on listed securities to encourage new stock market Listings and Government earned more revenues because Listed companies PAY APPROPRIATE TAX, unlike many private companies.

7) Privatization: Government must ensure that its Privatization programme remains on course to kick-start the market; BPE should be energized to perform to expectation.

8) Regulatory Oversight: sound and effective corporate governance; the regulatory authorities of the Nigerian Capital Market and of the whole financial sys- 
tem must ensure that the approved code of corporate governance is adhered to by all entities under their supervision. To guard against market abuses and insider trading, the monitoring units of these agencies must be strengthened and well equipped to perform their functions. Also, SEC (Securities and Exchange Commission) must not ignore its Developmental functions to grow the market; this function must not be left for the stock exchange and market operators alone... for you must bake the cake before you can eat it.

9) Federal Government should Fund SEC 100\% SEC as government regulator of the Capital Market should be fully funded by the Federal Government. At the moment, SEC is partly dependent on the market fees and penalties collected from the market operators. This may have the tendency of compromising its regulatory functions.

10) Mergers of Stockbroking Firms; Stock broking firms should be encouraged to come together, either through merger or outright acquisition. This will make them stronger and more viable and it will enhance good corporate governance and professionalism in the affected entities. As at today many of the surviving stockbroking firms that are too weak financially to stand alone may be allowed to practice as Broker/Dealer only without Portfolio Management.

11) Dematerialization: e-dividends, e-certificates; this means the conversion of share certificates from paper form into electronic format as in the CSCS-the Clearing House of the Nigerian Stock Exchange. A specific time frame (3 - 6 months) when the market will be fully dematerialized should be announced by SEC, NSE and Registrars. Same goes for dividend payments.

12) Unclaimed Dividends/Unclaimed Certificates; A large portion of Unclaimed Dividends and Certificates emanated from the 1972 and 1977 indigenization when photocopying machines were not available for people to keep track of their signatures. A lot of those unclaimed instruments are Statute Barred (12 years). There is absolutely no need to establish a new inefficient parastatal for unclaimed dividend. The Law in CAMA is that after 12 years, the money should be utilized by the company concerned to create more wealth for shareholders. In practice, if the beneficiaries of a late investor appear, The Stock Exchange always persuades the company to pay.

13) A strong Government Bail-out as obtained in USA, Britain, Russia, Singapore etc. is the magic wand needed. Asset Management Corporation of Nigeria (AMCON) was set up by $\mathrm{CBN}$ to buy these toxic assets (Margin Loans) with the hope of divesting when the market picks up. However, the modus operandi of AMCON in this respect seems unconcerned as far as market operators and shareholders are concerned.

14) Appointment of Market Makers and their Fund Providers; in April 2010, The Nigerian Stock Exchange appointed market makers who would provide market liquidity and stock-lending. The market makers could not take off in 2010 because the CBN did not approve their proposed Fund Providers (Deposit Money Banks). Now that the NSE has re-appointed them, investors need to 
know more details in this area of market markers recently appointed. What securities are they making market on? Are the selected market markers well-funded to undertake this role of buyer and seller of last resort? Have their Fund Providers been approved by the Regulator? How much money is the Transaction Float? Certainly this policy will encourage new investors, especially the retail investors. This is a quick-win solution...if properly implemented.

15) Listing of Upstream Oil Companies/Telecom Companies; the Federal Government should encourage the Upstream Oil companies and the major Telecoms companies to list on the Daily official list of the Nigerian Stock Exchange. However, the Government should induce them by introducing tax holidays, and other incentives such as Government contracts to make listing attractive to them. The truth is that all these companies are listed in their home countries; why are they refusing to list in Nigeria? In addition, more indigenous quotable companies should be encouraged to seek listing, by giving those incentives like tax holidays, tax rebate and other incentives. This will boost the economy by generating more jobs and government will get more tax revenue. Furthermore, their listing will enhance transparency of financial disclosure in their operations. One incentive that never fails is a policy of Government that ONLY Companies Quoted/Listed on the local Stock Exchange can get Government contracts above certain amount (N2Billion Naira.).

\section{References}

[1] Abu, N. (2009) Does Stock Market Development Raise Economic Growth? Evidence from Nigeria. Journal of Banking and Finance, 1, 15-26.

http://citeseerx.ist.psu.edu/viewdoc/download?doi=10.1.1.669.975\&rep=rep1\&type $=\mathrm{pdf}$

[2] Adamu, J.A. and Sanni, I. (2005) Stock Market Development and Nigerian Economic Growth. Journal of Economic and Allied Fields, 2, 116-132. https://ijbssnet.com/journals/Vol_6_No_9_1_September_2015/4.pdf

[3] Alile, H.I. (1984) The Nigerian Stock Exchange: Historical Perspective, Operations and Contributions to Economic Development. Central Bank of Nigeria Bullion, Silver Jubilee Edition, 2, 65-69.

[4] Nyong, M.O. (1997) Capital Market Development and Long-Run Economic Growth: Theory, Evidence and Analysis. First Bank Review, December 1997, 13-38.

[5] Akingbohungbe, S.S. (1996) The Role of the Financial System in the Development of the Nigerian Economy. Paper Presented at a Workshop Organized by Centre for Africa Law and Development Studies. http://www.egx.com.eg/pdf/fd_ribaf.pdf

[6] Alile, H. and Anao, A. (1986) The Nigerian Stock Market in Operation. Jeromelaiho and Associate Limited, Lagos.

[7] Bencivenga, V.R., Smith, B.D. and Starr, R.M. (1996) Equity Markets, Transaction Costs, and Capital Accumulations: An Illustration. The World Bank Review, 10, 241-265. https://doi.org/10.1093/wber/10.2.241

[8] Bolbol, A., Fatheldin, A. and Omran M. (2005) Financial Development, Structure and Economic Growth. The Case of Egypt, 1974-2002. Research in International Business Finance, 19, 171-194. http://www.egx.com.eg/pdf/fd_ribaf.pdf https://doi.org/10.1016/j.ribaf.2004.10.008 
[9] Dozie, S. (1998) Money, Banking and Financial Market. Pearson International, USA.

[10] Eichengreen, B. and Musa, M. (1998) Capital Account Liberation and the IMF. Finance and Development, December 1998.

[11] Ewah, S.O.E., Essang, A.E. and Bassey, J.U. (2009) Appraisal of Capital Market Efficiency on Economic Growth in Nigeria. International Journal of Business and Management, 4, 219-225.

http://www.ccsenet.org/journal/index.php/ijbm/article/view/4517 https://doi.org/10.5539/ijbm.v4n12p219

[12] Francis Xavier, R. and Raja, A.V. (2007) Stock Market and Shareholders Protection: Are They Important for Economic Growth? The Law and Development Review, 3 , 306-325.

https://www.degruyter.com/view/j/ldr.2010.3.2/ldr.2010.3.2.1020/ldr.2010.3.2.1020. $\mathrm{xml}$

[13] Gursoy, C.T. and Muslumov, A. (1999) Stock Markets and Economic Growth: Causality Test. MBA Thesis Submitted to the Institute of Social Sciences, Istanbul Technical University Turkey, 124-131.

[14] Hamid, M. and Sumit, A. (1998) Stock Market Development and Economic Growth Evidence from Developing Countries. http://faculty.apec.umn.edu/mohta001/PA1-4-01.pdf

[15] Johnson, J., Schnytzer, A. and Liu, S. (2009) To What Extent Do Investors in a Financial Market Anchor Their Judgments? Evidence from the Hong Kong Horserace Betting Market. Journal of Behavioral Decision Making, 22, 410-434.

https://ideas.repec.org/p/biu/wpaper/2011-05.html https://doi.org/10.1002/bdm.640

[16] Levine, R. and Zervos (1996) Stock Market Development and Long-Run Growth. The World Bank Economic Review, 10, 323-339. https://doi.org/10.1093/wber/10.2.323

[17] Luintel, K. and Khan, M. (1999) A Quantitative Re-Assessment of Finance-Growth Nexus: Evidence from a Multivariate VAR. Journal of Development Economics, 60, 381-405. http://www.sciencedirect.com/science/article/pii/S0304387899000450 https://doi.org/10.1016/S0304-3878(99)00045-0

[18] Muhammed, S., Nadeem, A. and Liaquat, A. (2008) Stock Market Development and Economic Growth: ARDL Causality in Pakistan. International Research Journal of Finance and Economic Issues, 14, 183-195.

http://citeseerx.ist.psu.edu/viewdoc/download?doi=10.1.1.453.2757andrep=rep 1 and type $=$ pdf

[19] Nieuwerburgh, S., Buelens, F. and Cuyvers, L. (2005) Stock Market Development and Economic Growth in Belgium.

https://www.google.com/url?q=http://people.stern.nyu.edu/svnieuwe/pdfs/BXSEEH final.pdf\&sa=U\&ved=0ahUKEwizw5O4ntXbAhUIvBQKHV8vBpwQFggVMAM\& usg=AOvVaw3_8HycUxT5I75ZGauSXzIX

[20] Nwankwo, G.O. (1991) Money and Capital Market in Nigeria Today. University of Lagos Press, Lagos.

[21] Nyong, M.O. (2003) Predictability and Volatility of Stock Return in Three Emerging Markets: Nigeria, South Africa and Brazil. Nigeria Journal of Economics and Development Matters, 2, 12-29.

http://www.academix.ng/demo/search/paper.html?idd=3300015916

[22] Obamiro, J.K. (2005) Nigerian Economy: Growth and the Role of Stock Market. 
Journal of Economic and Financial Studies, 2, 23-35.

http://www.iosrjournals.org/iosr-jhss/papers/Vol6-issue6/K0666068.pdf?id=5956

[23] Ogini, N. (1992) Importance of Capital Formulation in Underdeveloped Countries. Oxford University Press, New York.

[24] Oladeji, P. (1992) Introduction to Security Market Analysis and Portfolio Management. Limbs Press, Lagos.

[25] Oni, S. (1998) Relevance of the Nigerian Stock Exchange to the Economy. Unilag Symposium, Lagos. 